\title{
Relationship between Consumers' Exploring Cosmetics Information Behavior and Satisfaction and Recommendation Intention
}

\author{
Hyo-Jeong Sohn ${ }^{1}$, Seon-Hee You ${ }^{2}$, Cho-hi Park ${ }^{3 *}$ \\ ${ }^{1}$ Department of Cosmetics Engineering, Konkuk University, Seoul, Korea \\ ${ }^{2}$ Department of Beauty Stylist-Major in Skin Care, Yeonsung University, Anyang-si, Gyeonggi-do, Korea \\ ${ }^{3}$ Department of Beauty Industry, Sungshin University, Seoul, Korea
}

*Corresponding author: Cho-hi Park. Department of Beauty Industry, Sungshin University, 55, Dobong-ro 76ga-gil, Gangbuk-gu, Seoul 01133, Korea

Tel.: +8229202648

Fax: +82 29202140

Email: chohi@sungshin.ac.kr

Received October 21, 2019

Revised December 05, 2019

Accepted December 10, 2019

Published December 30, 2019

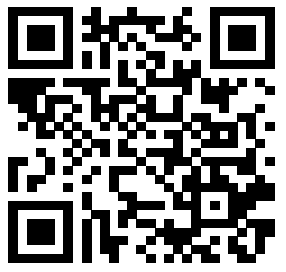

\begin{abstract}
Purpose: This study was aimed at providing greater insight and understanding regarding female cosmetics consumers in their twenties marketing cosmetics, by assessing their influence on, and relationship with, their satisfaction and recommendation intentions. This study focuses on women in their twenties who are actively interested in the beauty and cosmetics industry and have ease in terms of searching for relevant information. Methods: The collected data were analyzed by the SPSS WIN 25.0 program. We calculated the frequency and percentage to identify not only the general characteristics of the study subjects but also the underlying utilization characteristics regarding inquiries and information on cosmetics. Furthermore, a regression analysis and an intermediate effects analysis were conducted to identify the effects and relationships between these factors. In addition, a reliability analysis was employed and so was a correlation analysis between the derived factors and the degree of recommendation of cosmetics information and satisfaction. Results: Our analysis exhibited a relatively high correlation between customer purchasing satisfaction and recommendation intention. Furthermore, regression analysis results showed that recommendation intention had a significant effect on information search for cosmetics and that satisfaction showed a medial effect when information search behavior for cosmetics affected recommendation intention. Conclusions: This study highlights that when consumers provide reliable and objective information that is, in turn, used as a marketing tool for cosmetics, they are more likely to expect positive marketing effects and recommendations.
\end{abstract}

Keywords: Consumers, Cosmetic information, Satisfaction, Recommendation Intention, Utilization characteristics

\section{Introduction}

정보통신 기술의 발달과 스마트폰의 대중화로 화장품 소비시장 의 흐름은 오프라인 매장에서 온라인 화장품 쇼핑몰로 1차변화를 겪었으며 모바일 앱, SNS 이용빈도가 늘어나고 고객들의 소비영역 이 확장되고 있다. 시간과 공간의 제약이 사라지고 정보를 주고받 기 편리해졌으며 소비경험을 공유함으로써 다양한 커뮤니티 활동 및 네트워크를 형성할 수 있게 되었다. 모바일을 통한 전자상거래
를 기반으로 광고부터 구매와 결제까지 실시간으로 가능하고 제품 의 모든 정보를 검색부터 구매까지 가능하다(Joung, 2019; Kwak et al., 2012). 이러한 이유에는 대중들의 생활 속에 스마트폰이 자 동화와 편리함을 더욱 극대화한 것으로 볼 수 있다(Kim, 2018). 온 라인 쇼핑의 연간 증가율은 유통시장 전체에서 가장 높다. 소비자 는 인터넷, 스마트폰 등의 온라인 환경을 이용하여 다양한 정보를 수집하면서 화장품을 구매하는 경향은 꾸준히 증가하고 있다(Lee et al., 2012). 
화장품은 소비자의 경험을 필요로 하는 경험재로 소비자에게 제 시된 정보를 통한 간접경험만으로는 확신할 수 없는 온라인 거래에 제한점이 있음에도 불구하고 높은 성장세를 나타내고 있다. 화장품 의 온라인 구매는 이동 및 탐색 비용이 절감되고 제품과 가격의 비 교가 용이하며 협상이나 인적 거래의 부담감이 적다는 장점이 있다 (Kim \& Oh, 2018; Lee et al., 2012).

소비자들은 제품을 구매하기 전 제품선택에 필요한 정보를 탐 색하여 의사결정에 반영하는데 이를 정보탐색이라 한다. 화장품 은 대표적인 소비재이기도 하기에 화장품에 대한 정보 탐색에 상당 히 많은 시간과 노력을 할애한다. 이는 소비자의 구매행동과 연결 되며 제품의 구매와 사용경험, 다른 사람사람부터 얻게 된 구전정 보, 대중매체의 광고나 인터넷으로 알게 되는 정보 등 다양한 경험 적 학습과 인지적 학습의 결과로 구매태도가 형성된다(Yong \& Jin, 2018; Koo \& Rha, 2015). 화장품 관련 정보의 탐색은 주로 온라 인 환경에서 이루어지고 있다. 온라인 환경에서의 정보공유는 온라 인 구전을 생기게 하고 이는 신뢰를 형성하게 되며 입소문 마케팅 (viral marketing)을 생성시킨다. 이렇게 형성된 브랜드의 이미지 는 한동안 상대적으로 고정되며 안정성을 발휘한다. 온라인 구전을 통해 긍정적인 이미지가 형성되면 소비자의 마음속에서 쉽게 변하 지 않는다(Zheng \& Noh, 2016), 화장품의 정보탐색은 주로 온라 인에 남겨지는 리뷰, 경험을 전달하는 구전 형태로 이루어 지게 된 다. 정보탐색의 개념은 1923 년 Copeland에 의해 처음 연구되기 시 작하였고 학자들에 따라 조금씩 다르게 정의되고 있지만, 정보탐 색을 의사결정 과정의 일부로써 의사결정을 용이하게 하기 위한 과 정으로 보고 구매하고자 하는 제품 및 대체안에 관한 정보를 얻기 위해 소비자가 행하는 모든 노력이라는 일관된 견해를 갖고 있다 (Kang \& Lee, 1998). 온라인 정보탐색의 유형은 특정 동기나 혜택 을 추구하는 성향을 이용하여 목표지향적(goal-directed) 행동과 경험적(experiential)행동으로 구분할 수 있다. 목표 지향적 행동 은 특정 쇼핑목표에 기인하며, 경험적 행동은 즉흥적이고 탐색적이 며 즐거움을 추구하는 성향을 보인다. 이러한 행동은 정보탐색활동 의 측면에서 구매 전 정보탐색과 지속적 정보탐색의 형태로 구분하 며 이는 서로 다른 동기에 의해 유발된다(Kim \& Ye, 2009). 즉, 구 매라는 뚜렷한 목표를 가지고 문제해결을 위한 이성적인 행동에 초 점을 둔 목표지향적 행동은 실용적 동기에서 유발하여 구매 전 탐 색 행동을 보이는데 반해, 정보를 탐색하는 과정 자체에서 얻는 즐 거움에 초점을 둔 경험 지향적행동은 쾌락적 동기가 시작이며 구매 목표없이 지속적 정보탐색의 행동을 보인다(Park \& Jung, 2013).

일반적으로 사용되는 '만족시키다'의 개념은 영어의 어휘적 의미 로 볼 때 '가득 차도록 충족시킨다'는 뜻으로 만족시키는 제품과 서 비스는 고객이 요구하는 것을 충분한 정도까지 제공할 능력을 가지 고 있는 것으로 본다(Go et al., 2015). 소비자의 만족도는 소비자 가 제품을 구매하여 사용하면서 경험하는 제품의 성과로, 구매한 상품에 대한 만족감을 느끼는 것이 소비자의 근본적 목적이다. 소
비자의 만족도가 중요한 이유는 재구매 결정에 주요한 역할을 함으 로써 불만족의 경우 만족하지 못한 제품에 대한 불평이 공론화되 거나 부정적인 말들이 전파되어 결국 쇼핑행동의 변화를 야기시킬 수 있기 때문이다. 화장품은 한번 사용하여 자신의 피부에 잘 맞고 기호에 만족하면 지속적으로 같은 브랜드를 사용하는 습성이 있고 이에 대한 소비자 만족은 재구매만이 아니라 상표 충성도에 영향 을 주고 나아가 구전효과에도 긍정적인 영향을 미친다(Lee et al., 2017; Park \& Ku, 2011).

추천의도는 '서비스 기업에서 발생하는 긍정적 구전활동의 범주 에 속하는 개념으로 고객이 만족감을 느끼고 지각한 서비스와 상품 의 정보를 주변에 알리고 적극으로 구매를 유도하는 고객의 행동 의도'를 의미하는 것으로 다시 말해, 고객이 상품을 구매하고 이용 한 후 만족한 경우, 주변의 잠재 고객들에게 해당상품에 대해 적극 적으로 구매를 권유하는 의도로 파악된다(Cronin \& Taylor, 1992; $\mathrm{Kim} \& \mathrm{Ha}, 2016)$. 추천의도는 고객후속행동 결과에 해당하고 추 천은 구전현상의 하나로 개인적 경험을 통해 얻어진 긍정적·부정 적 내용이 내포되어 있는 정보를 교환하는 커뮤니케이션 행위이다 (Ryu \& Lee, 2013).

소비자의 화장품 정보탐색에 관한 선행연구로는 북경 여성 소 비자의 화장품 정보탐색에 관한 연구(Zhang \& Koo, 2017), 여 성소비자의 정보탐색유형별 화장품 구매성향연구(Kim \& Rhee, 2007), 점포유형에 따른 한방화장품 소비자의 정보 탐색과 구매 실 태(Choi, 2011), 멀티채널 소비자의 정보탐색 및 구매 채널 선택에 관한 연구(Lee et al., 2012)등의 다양한 연구들이 진행되어 왔다. 그러나 소비자의 정보탐색 유형과 구매 성향의 연관성, 구매 실태 등을 알아보는 연구들이 대부분이었다. 화장품 구매와 사용에 있어 서 정보탐색은 이제 빼놓고 생각 할 수 없는 부분이 되었기에 화장 품 정보탐색행동이 구매 후 소비자 행동에 미치는 영향에 대한 연 구가 필요하다. 따라서 본 연구에서는 뷰티와 화장품에 관심이 많 고 정보탐색 및 검색에 어려움이 없는 20 대 여성을 중심으로 화장 품 구매를 위해 시도하는 정보 탐색행동이 만족도와 추천의도에 미 치는 영향과 관계를 규명함으로써 화장품 시장의 마케팅 대상인 20 대 여성 화장품 소비자를 이해할 수 있는 자료를 제공하고 소비자 중심의 화장품 정보제공 및 접근방법의 다양화 방안을 제시하고자 한다.

\section{Methods}

\section{1. 연구대상 및 자료수집}

본 연구의 주제인 화장품의 뷰티 정보 탐색행동이 구매만족도와 추천의도에 미치는 영향을 알아보기 위해 2019년 6월 18일부터 6 월 25 일까지 뷰티 정보탐색 후 화장품을 구매한 경험이 있는 20 대 여대생과 회사원 206 명을 대상으로 설문조사를 실시하였다. 206부 
의 설문지 중 분석에 사용되기 어려운 결측값이 있는 20 부를 제외 한 나머지 186 부를 최종 분석자료로 사용하였다.

\section{2. 측정도구}

본 연구를 위한 설문지의 문항은 선행연구의 고찰을 바탕으로 하여 수정, 보완하여 구성하였다. 선행연구(Chang \& Lee, 2010; Lee et al., 2017; Yong \& Jin, 2018;Zhang \& Koo, 2017)를 참 고로 하여 화장품 정보탐색 8문항, 구매만족도 7문항으로 구성하고 추천의도에 관한 문항 5 문항(Reynolds \& Beatty, 1999)으로 구성 하고 조사대상자가 동의하는 정도를 5 점 리커트 척도로 측정하였 다. 그 외에 인구통계적 특성 5 문항, 이용특성에 관한 5 문항은 명 목척도로 구성하였다.

\section{3. 분석방법}

본 연구를 위해 수집된 자료는 Statistical Package for the Social Science (SPSS) WIN 25.0 프로그램(IBM, USA)를 이용해 분석하였다. 연구대상자의 일반적특성을 파악하기 위해 빈도 및 백 분율을 산출하였고, 연구에 사용된 문항의 타당성 검증과 공통요인 을 찾아 변수로 활용하기 위한 요인분석 및 신뢰도 분석을 실시하 였다. 소비자의 화장품 정보탐색 행동 후 구매한 화장품의 만족도 와 추천의도와의 관계를 파악하기 위해 상관분석을 실시하였으며, 구매만족도와 추천의도가 화장품정보탐색행동에 미치는 영향을 알
아보기 위해 회귀분석을 실시하였다. 또한, 화장품 정보탐색행동과 추천의도와의 관계에서 만족도가 매개 역할을 하는지 알아보기 위 해 매개효과 분석을 실시하였다.

\section{Results and Discussion}

\section{1. 연구대상자의 일반적 특성}

연구대상의 일반적 특성을 파악하기 위해 빈도분석(frequency analysis)을 실시하였으며 그 결과는 Table 1과 같다. 조사대상 총 188 명 중 성별은 남성 $4.8 \%$ 여성 $95.2 \%$ 로 조사되었고 연령별로 는 10 대 $2.7 \%, 20$ 대 $84.6 \%, 30$ 대 $9 \%, 40$ 대 $3.7 \%$ 를 차지하였다. 학력별 분포는 대학 재학 중 $81.9 \%$, 대학원 졸 $7.4 \%$, 고졸 $5.4 \%$, 대졸 $5.3 \%$ 순으로 나타났다. 직업별 분포는 학생 $84.6 \%$, 회사원 $7 \%$, 자영업 $6.4 \%$, 기타 $5.3 \%$, 주부 $1.6 \%$ 순으로 나타났고 월 소 득 분포는 100 만원 이하 $86.1 \%$ 200-299만원 6.9\%,300만 이상 $3.7 \%, 100-199$ 만원 $3.2 \%$ 순으로 조사되었다.

\section{2. 화장품 정보탐색 이용특성}

연구대상자의 화장품 정보탐색의 이용특성을 파악하기 위해 빈 도분석을 실시하였으며 그 결과는 Table 2 와 같다. 화장품에 대한 정보 습득 채널을 묻는 설문에서 $\mathrm{SNS}$ (페이스북, 인스타그램, 트위

Table 1. General characteristics of the population included in this study

$(\mathrm{N}=188)$

\begin{tabular}{|c|c|c|c|}
\hline Classification & & Frequency $(\mathrm{N})$ & Percentage (\%) \\
\hline \multirow{2}{*}{ Gender } & Male & 9 & $4.8 \%$ \\
\hline & Female & 179 & $95.2 \%$ \\
\hline \multirow{4}{*}{ Age } & $10 \mathrm{~s}$ & 5 & $2.7 \%$ \\
\hline & $20 s$ & 159 & $84.6 \%$ \\
\hline & $30 \mathrm{~s}$ & 17 & $9.0 \%$ \\
\hline & $40 s$ & 7 & $3.7 \%$ \\
\hline \multirow{4}{*}{ Academic background } & High school diploma & 10 & $5.4 \%$ \\
\hline & While in collage & 154 & $81.9 \%$ \\
\hline & University graduate & 10 & $5.3 \%$ \\
\hline & Post graduate school & 14 & $7.4 \%$ \\
\hline \multirow{5}{*}{ Profession } & Employee & 13 & $7.0 \%$ \\
\hline & Self-employment/business & 3 & $6.4 \%$ \\
\hline & Housewife & 3 & $1.6 \%$ \\
\hline & Student & 159 & $84.6 \%$ \\
\hline & Others & 10 & $5.3 \%$ \\
\hline \multirow{4}{*}{ Monthly household income } & Under $1,000,000$ won & 162 & $86.1 \%$ \\
\hline & $1,000,000-1,990,000$ won & 6 & $3.2 \%$ \\
\hline & $2,000,000-2,990,000$ won & 13 & $6.9 \%$ \\
\hline & Over $3,000,000$ won & 7 & $3.7 \%$ \\
\hline
\end{tabular}


터 등) $37.8 \%, 1$ 인미디어 방송(유튜브, 아프리카TV 등) $27.7 \%$, 뷰 티 어플리케이션(화해, 글로우픽, 언니의파우치 등) $16 \%$, 블로그 $12.2 \%$, 온라인 쇼핑몰 $6.4 \%$ 의 순으로 나타났다. 과거에는 구매 경험에 가장 많이 의지하며 화장품 정보를 수용하였고 가족, 친구, 지인 등의 정보원을 통해 화장품에 대한 정보를 탐색하거나 TV 광 고 등의 매체, 연예인 및 유명인이 사용하는 것을 탐색하는 오프 라인 위주의 정보 탐색이었다면(Sung \& Lee, 2006), 현재는 모 바일 환경의 발달로 온라인 환경에서의 정보탐색으로 변화된 것 을 알 수 있다. 화장품 정보탐색을 위해 정보 습득 채널의 한달 평 균 사용횟수는 묻는 설문에서는 3-5회 사용이 $30.3 \%, 10$ 회 이상 사용이 $29.8 \%, 1-2$ 회 사용이 $28.7 \%, 6-9$ 회 사용이 $11.2 \%$ 순으 로 나타났다. 화장품 정보탐색의 월 평균 횟수가 3-5회 사용과 10 회 이상 사용이 총 $60.1 \%$ 로 상당히 높은 비율로 조사되었다. 화장 품 정보탐색 1 회당 사용 평균시간을 묻는 질문에서는 $10 \mathrm{~min}$ 이상 $30 \mathrm{~min}$ 미만이 40.4\%, 5-10 $\mathrm{min}$ 미만 29.3\%, $30 \mathrm{~min}$ 이상 $1 \mathrm{~h}$ 미만 $18.1 \%, 5 \mathrm{~min}$ 미만 $12.2 \%$ 순으로 조사되어 화장품의 정보탐
색을 위해 정보탐색 채널에 머무르는 시간이 꾀 긴 시간이라는 것 을 알 수 있다. 온라인 정보채널 사용 시 선호하는 정보의 유형을 묻는 설문에서는 동영상 $67 \%$, 사진 $23.9 \%$, 글(문자) $8.5 \%$, 그림 $0.5 \%$ 순으로 나타나 점점 정보탐색의 선호 유형이 동영상 형태로 옮겨가는 추세임을 알 수 있다. 이는 온라인 정보검색의 패턴이 블 로그에서 유튜브로 옮겨가는 현재의 흐름을 따르는 결과로 해석된 다. 화장품 정보채널의 사용목적을 묻는 설문에서는 제품적합도 관 련 정보 습득 $71.8 \%$, 사용 관련정보 습득 $16 \%$, 행사 관련정보 습 득 $6.9 \%$ 이미지 관련정보 습득이 $5.3 \%$ 순으로 나타났다. 이 결과 를 통해 화장품을 구매하거나 구매 예정에 있는 화장품의 정보를 탐색할 때 본인 피부타입, 기능, 가격 등의 정보를 가장 중요하게 여기는 것으로 나타났다.

\section{3. 측정변수의 요인분석 및 신뢰도 분석}

본 연구의 측정 변수는 척도 순화과정을 통해 일부 항목을 제 거하고 타탕도를 검증하기 위한 탐색적 요인분석을 실시한 결과

Table 2. Characteristics of the utilized online information channels

$(\mathbf{N}=\mathbf{1 8 8})$

\begin{tabular}{|c|c|c|c|}
\hline Classification & & Frequency (N) & Percentage (\%) \\
\hline \multirow{5}{*}{$\begin{array}{l}\text { Mainly used cosmetics } \\
\text { information channels }\end{array}$} & Social networking service & 71 & $37.8 \%$ \\
\hline & Beauty application & 30 & $16.0 \%$ \\
\hline & Personal media broadcasting & 52 & $27.7 \%$ \\
\hline & Blog & 23 & $12.2 \%$ \\
\hline & Online cosmetics shopping mall & 12 & $6.4 \%$ \\
\hline \multirow{4}{*}{$\begin{array}{l}\text { Monthly average } \\
\text { utilization rate }\end{array}$} & 1-2 times & 54 & $28.7 \%$ \\
\hline & 3-5 times & 57 & $30.3 \%$ \\
\hline & 6-9 times & 21 & $11.2 \%$ \\
\hline & Over 10 times & 56 & $29.8 \%$ \\
\hline \multirow{4}{*}{ Preferred information type } & Photo & 45 & $23.9 \%$ \\
\hline & Video & 126 & $67.0 \%$ \\
\hline & Letter & 16 & $8.5 \%$ \\
\hline & Picture & 1 & $0.5 \%$ \\
\hline \multirow{4}{*}{ Purpose of use } & Obtain information about promotions and events. & 13 & $6.9 \%$ \\
\hline & Obtain information about capacity, components, and precautions. & 30 & $16.0 \%$ \\
\hline & $\begin{array}{l}\text { Obtain information related to function, skin type, price, and product } \\
\text { suitability. }\end{array}$ & 135 & $71.8 \%$ \\
\hline & $\begin{array}{l}\text { Obtain image related information about the respective design, } \\
\text { advertisement model, brand image, etc. }\end{array}$ & 10 & $5.3 \%$ \\
\hline
\end{tabular}


는 Table 3 과 같다. 모든 측정 변수는 구성 요인을 추출하기 위해 서 공통요인분석(common factor analysis, CFA)을 사용하였으며, 사회과학 연구의 경우 주로 사용하는 사각회전 직접 오블리민 회 전방식(Roh, 2014)을 채택하여 결과를 도출해 낸 결과 '현재 사용 하는 제품에 대한 좋은 평가를 전달할 것이다'와 '현재 사용하는 화 장품은 가격에 비해 우수하다' 항목을 제외하고 3 가지 요인이 추출 되었다(설명량: $68.519 \%$ ). 추출된 요인은 추천의도, 화장품 정보 탐색, 만족도로 명명하였다. 추천의도의 설명량은 $47.062 \%$, 화장 품 정보탐색의 설명량은 $15.534 \%$, 만족도의 설명량은 $5.926 \%$ 이 며, 본 연구의 문항 선택 기준은 고유값(eigen value)은 1.0 이상, 요인 적재치는 0.40 이상을 기준으로 작성하였다. 총 20 개 문항 중 2 개 문항이 이론 구조에 맞지 않게 적재되어 제거하고 최종적으로 18 개의 문항을 분석에 사용하였다. 문항의 신뢰도 분석은 측정하
고자 하는 개념이 설문 응답자로부터 정확하고 일관되게 측정되었 는가를 확인하는 것이다(Song, 2015) 각 문항의 신뢰도 분석결과 Cronbach' alpha 값은 추천의도 0.905, 화장품 정보탐색 0.910, 만족도 0.892 높게 나타나 측정도구의 정확성이 검증되었다. 표본 적합도를 의미하는 Kaiser-Meyer-Olkin (KMO)의 값은 0.904로 $\mathrm{KMO}>0.5$ 를 만족하여 적합한 것으로 분석되었고, Bartlett의 구형 성 검증 값은 $p<0.01$ 로 $p<0.5$ 를 만족하여 요인분석이 적절함이 검 증되었다.

\section{4. 화장품 정보탐색과 추천의도, 만족도의 상관관계}

요인분석을 통해 도출된 3 요인간의 관련성 정도와 방향을 파악 하기 위해 상관관계 분석을 실시한 결과는 Table 4와 같다. 각 변 수들 간에 유의수준 0.01하에서 상관관계가 있는 것으로 나타났으

Table 3. Classification factors

\begin{tabular}{|c|c|c|c|}
\hline \multirow[b]{2}{*}{ Classification } & \multicolumn{3}{|c|}{ Average } \\
\hline & $\begin{array}{l}\text { Recommendation } \\
\text { intention }\end{array}$ & $\begin{array}{l}\text { Exploring } \\
\text { cosmetic } \\
\text { information }\end{array}$ & Satisfaction \\
\hline 13. Recommend current products to people. & 0.924 & -0.025 & 0.079 \\
\hline 12. I will encourage people around me to buy the products that I use now. & 0.870 & -0.005 & 0.050 \\
\hline 15. Currently used products are presented to the neighborhood. & 0.602 & 0.116 & 0.061 \\
\hline 14. I will promote the advantages of current products in use. & 0.584 & 0.140 & 0.151 \\
\hline 21. Finding new beauty-related information is enjoyable. & -0.044 & 0.915 & -0.049 \\
\hline 20. Searching for beauty-related information is enjoyable and fun. & 0.106 & 0.764 & 0.040 \\
\hline 18. I search for information to compare various parameters and information. & 0.082 & 0.723 & -0.028 \\
\hline 17. I search for information on beauty to find related events. & 0.028 & 0.719 & -0.120 \\
\hline 16. I find beauty information regardless of time. & -0.132 & 0.711 & 0.179 \\
\hline 19. I search to satisfy my curiosity. & -0.098 & 0.697 & 0.205 \\
\hline 22. I take a closer look at the style of an acquaintance or passerby. & 0.116 & 0.686 & -0.040 \\
\hline 23. I carefully watch celebrity and beauty influencers' styles. & 0.137 & 0.624 & -0.047 \\
\hline 9. I am satisfied with the safety of the cosmetics I use now. & 0.050 & -0.113 & 0.808 \\
\hline 6. I am satisfied with the function and the results of the cosmetics that I use now. & 0.027 & 0.085 & 0.778 \\
\hline 7. I think it may be wise to choose the cosmetics you are using now. & -0.025 & 0.096 & 0.754 \\
\hline 10. The cosmetics I use are suitable for my skin. & 0.105 & 0.011 & 0.714 \\
\hline 8. The ingredients of the cosmetics I use are excellent. & 0.125 & -0.011 & 0.622 \\
\hline 11. I will provide a good evaluation of the products I currently use. & 0.354 & 0.071 & 0.401 \\
\hline Unique value & 7.718 & 2.578 & 0.823 \\
\hline Dispersion (\%) & 47.062 & 15.534 & 5.926 \\
\hline Accumulated description (\%) & 47.062 & 62.596 & 68.519 \\
\hline Cronbach alpha & 0.905 & 0.910 & 0.892 \\
\hline KMO & & & 0.904 \\
\hline Bartlett‘s Test of Sphericity & $\begin{array}{l}\text { Chi-square } \\
\text { Df }(p)\end{array}$ & & $\begin{array}{c}2411.209 \\
153(0.000)\end{array}$ \\
\hline
\end{tabular}

KMO, Kaiser-Meyer-Olkin; Df, degree of freedom.

Table 4. Correlation variables

\begin{tabular}{|c|c|c|c|c|c|}
\hline \multirow{2}{*}{ Classification } & \multirow{2}{*}{ Mean } & \multirow{2}{*}{ SD } & \multicolumn{3}{|c|}{ Inter-construct correlations } \\
\hline & & & 1 & 2 & 3 \\
\hline Satisfaction & 3.6225 & 0.67627 & 1.000 & & \\
\hline Recommendation intention & 3.6032 & 0.68386 & $0.751^{* *}$ & 1.000 & \\
\hline Exploring cosmetic information & 3.4913 & 0.75673 & $0.410^{* *}$ & $0.526^{* *}$ & 1.000 \\
\hline
\end{tabular}

SD, standard deviation; ${ }^{* *} p<0.01$. 
며 구체적으로 구매만족도와 추천의도는 0.751 , 구매만족도와 정 보탐색은 0.410 으로 추천의도와의 상관관계가 비교적 높은 상관관 계를 보였으며, 추천의도와 정보탐색은 0.526 의 상관계수 값을 나 타낸 것으로 분석되었다.

\section{5. 화장품 구매 후 느낀 만족감과 추천의도가 화장품 정보탐색행동 에 미치는 영향}

소비자가 화장품 구매 후 느낀 만족감과 추천의도가 화장품 정 보탐색행동에 미치는 영향을 알아보기 위하여 다중회귀분석을 실 시한 결과를 Table 5에 표시하였다.

회귀모형의 설명력은 $\mathrm{R}^{2}=0.277$ 으로 $27.7 \%$ 의 설명력을 보이 고 회귀식은 통계적으로 유의미한 것으로 분석되었다 $F=35.132$, $p$ <0.000). Durbin-Watson는 1.935로 잔차들 간에 상관관계가 없어 회귀모형이 적합한 것으로 확인되었다. 독립변수별로 만족 도가 뷰티 정보 탐색행동에 미치는 영향관계를 검정한 결과 $\mathrm{t}$ 값이 0.361 ( $p=0.719)$ 로 나타나 만족도는 뷰티 정보탐색 행동에 부(-) 의 영향을 미치는 것으로 나타났고, 추천의도는 뷰티 정보탐색에 대해 $t$ 값이 5.256 ( $p=0.000)$ 로 나타나 추천의도가 뷰티 정보탐색 에 유의미한 정(+)의 영향을 미치는 것으로 분석되었다. 즉, 만족 도는 개인의 만족감이 우선인 감정이므로 뷰티 정보탐색 행동을 통 해 객관성을 확보할 필요가 없지만 추천의도는 타인에게 정확하고 신뢰할 수 있는 제품을 선별하여 제공하여야 하기 때문에 뷰티 정
보탐색을 통해 객관적이고 신뢰성이 확보되었으며, 다른 구매자들 이 공인한 제품을 추천하려는 의도가 중요한 요인임을 알 수 있다.

\section{6. 화장품 정보탐색행동과 추천의도와의 관계에서 만족도의 매개 효과}

화장품 정보탐색행동과 추천의도와의 관계에서 만족도가 매개 역할을 하는지 알아보기 위해 Baron \& Kenny (1986)의 연구에 제시된 방법으로 3 단계 회귀분석을 실시하였다. Baron과 Kenny 의 매개 회귀 분석의 방법은 3 단계를 거치는데 1 단계는 '독립변수 $\rightarrow$ 매가변수'간의 유의성이 검정되어야 하고, 2 단계는 '독립변수 종속변수'간의 유의성이 검정된 후 3 단계에서 '독립변수, 매개변 수 $\rightarrow$ 종속변수'간의 유의성이 검정되고나서 2 단계와 3 단계의 $\beta$ 값 (표준화된 베타값)을 비교하였을 때 2 단계의 값이 3 단계 보다 커 야 매개효과가 인정된다(Roh, 2014). 분석 결과는 Table 6에 제시 된 것과 같다. 매개 효과 분석에서 만족도의 매개효과를 분석하기 위해 첫번째 단계로 뷰티 정보탐색행동을 독립변수로 만족도를 종 속변수로 설정하여 분석한 결과 1단계 회귀계수는 매개변수인 만 족감에 유의미한 영향 $(\beta=0.410, p<0.01)$ 이 있는 것으로 나타났으 며, 2 단계 회귀계수는 뷰티 정보탐색행동이 추천의도에 유의미 한 영향 $(\beta=0.526, p<0.01)$ 이 있는 것으로 나타났다. 마지막 3 단계 회귀계수는 뷰티 정보탐색과 $(\beta=0.262, p<0.01)$ 만족도 $(\beta=0.644$, $p<0.01)$ 가 추천의도에 유의미한 영향을 미치는 것으로 나타났다.

Table5. Factors influencing individuals to seek cosmetics information on satisfaction and recommendation intention

\begin{tabular}{|c|c|c|c|c|c|c|c|c|c|}
\hline Classification & Independent variable & B & SE & $\beta$ & $t$ & $p$ & $\begin{array}{l}\text { Durbin- } \\
\text { Watson }\end{array}$ & $\mathrm{R}^{2}$ & Limit \\
\hline Dependent variable & (Invariable) & 1.351 & 0.281 & & 4.807 & $0.000^{* * *}$ & \multirow{3}{*}{1.935} & \multirow{3}{*}{0.277} & \\
\hline \multirow{2}{*}{$\begin{array}{l}\text { Exploring beauty } \\
\text { information }\end{array}$} & Satisfaction & 0.040 & 0.111 & 0.034 & 0.361 & 0.719 & & & 0.436 \\
\hline & $\begin{array}{l}\text { Recommendation } \\
\text { intention }\end{array}$ & 0.554 & 0.105 & 0.500 & 5.256 & $0.000^{* * *}$ & & & 0.436 \\
\hline
\end{tabular}

B, unstandardized coefficients; SE, standard error; $\mathrm{R}^{2}$, R-squared; ${ }^{* * *} p<0.001$.

Table 6. Mediating effect of exploring beauty information on the relation between recommendation intention and satisfaction

\begin{tabular}{|c|c|c|c|c|c|}
\hline Model & Independent variable & Dependent variable & $\beta$ & $t$ & $p$ \\
\hline 1 & Exploring beauty information & Satisfaction & 0.410 & 6.103 & $0.000^{* * *}$ \\
\hline 2 & Exploring beauty information & Recommendation intention & 0.526 & 8.395 & $0.000^{* * *}$ \\
\hline \multirow{2}{*}{3} & $\begin{array}{l}\text { Exploring beauty information } \\
\text { (Independent variable) }\end{array}$ & \multirow{2}{*}{ Recommendation intention } & 0.262 & 5.256 & $0.000^{* * *}$ \\
\hline & $\begin{array}{l}\text { Exploring beauty information } \\
\text { (parameter) }\end{array}$ & & 0.644 & 12.910 & $0.000^{* * *}$ \\
\hline
\end{tabular}


뷰티 정보탐색행동이 추천의도에 미치는 영향이 2 단계의 표준화된 베타 값( $\beta=0.526)$ 이 3 단계의 표준화된 베타 값 $(\beta=0.262)$ 보다 크 므로 만족도가 매개효과가 있는 것으로 판단된다.

\section{Conclusion}

본 연구는 소비자의 화장품 정보탐색행동과 만족도 및 추천의도 와의 관계에 대한 연구로 20 대 여성을 중심으로 설문지법을 통하여 수집된 자료 188 부를 분석에 사용하였다. 소비자의 화장품 정보탐 색시 이용특성에 대해 분석하고, 각 변수들의 상호관련성과 구매한 화장품의 만족도와 추천의도가 화장품 정보탐색에 미치는 영향과 화장품 정보탐색 행동과 추천의도와의 관계에서 만족도의 매개효 과를 파악하고자 하였다. 연구문제에 따른 결론은 다음과 같다.

첫째, 화장품 소비자의 이용특성을 살펴본 결과 주로 화장품 정 보를 습득하는 채널은 SNS, 1 인 미디어방송, 뷰티어플리케이션, 블로그, 온라인 쇼핑몰 순으로 나타나 모바일 환경의 발달과 변화 로 일방적으로 매체 정보를 수용하거나 지인을 통해 얻던 화장품 정보의 습득이 온라인 환경의 정보탐색 수용으로 변화된 것을 알 수 있었다. 또한 정보습득 채널의 한달 평균 사용횟수는 3-5회 사 용이 가장 많은 답변을 얻었고, 화장품 정보탐색 시 1 회당 사용시 간을 묻는 질문에서는 10-30 $\mathrm{min}$ 사이가 가장 많은 답변을 얻었 다. 온라인 정보의 선호 정보 유형은 동영상이 $67 \%$ 로 조사되어 사 진과 글 형태의 정보형식에서 동영상 형식의 정보로 선호 정보 유 형이 변화된 것을 알 수 있었다. 화장품 정보채널의 사용 목적은 개 인의 피부와 맞는 제품 적합도 관련 습득이 가장 많은 부분을 차지 하는 것으로 조사되었다.

둘째, 소비자의 화장품 정보탐색과 관련하여 실시한 설문 문항의 요인분석을 실시한 결과 추천의도, 화장품 정보탐색, 만족도 3 가지 요인이 도출되었다. 분석된 3 가지 요인의 관련성 정도와 방향을 파 악하기 위해 상관관계를 분석한 결과 구매만족도와 추천의도가 비 교적 높은 상관관계를 보였고 만족도와 화장품 정보탐색행동의 상 관관계는 비교적 낮게 나타났다.

셋째, 소비자가 화장품 구매 후 느낀 만족도와 추천의도가 화장 품 정보탐색에 미치는 영향을 알아보기 위해 회귀분석을 실시한 결 과 만족도는 뷰티 정보 탐색행동에 유의미한 영향을 미치지 못하였 지만 추천의도는 화장품 정보탐색에 유의미한 정 $(+)$ 의 영향을 미치 는 것으로 분석되었다. 즉, 만족도는 개인의 감정이므로 객관성을 확보할 필요가 없지만 추천의도는 신뢰할 수 있는 정보를 제공하여 야 하기 때문에 화장품 정보탐색을 통해 객관적인 정보를 추천하려 는 의도가 중요한 요인인 것으로 분석된다.

넷째, 화장품 정보탐색 행동과 추천의도와의 관계에서 만족도의 매개 효과를 분석한 결과 화장품 정보탐색행동이 추천의도에 영향 을 미칠 때 만족도가 매개효과를 나타내는 것으로 분석되었다. 이
는 화장품 구매 시 추천을 하려는 의도가 있을 때 구매에 대한 만족 도나 정보에 대한 만족도를 얻어야 추천의도를 더 강하게 유발시키 는 것으로 생각된다.

이상의 연구결과로 화장품 정보를 주로 얻는 채널과 선호 유형을 알아볼 수 있었고 화장품을 추천하고자 하는 의도에 이르기 위해서 는 화장품 정보채널을 통해 얻는 정보의 만족도와 구매 후 만족도 가 매개 역할을 할 때 추천의도가 극대화된다는 것을 알 수 있었다. 본 연구는 화장품을 구매하기 전 후 정보탐색 이용특성과 현황을 확인하고 만족도의 매개효과를 확인한 것에 의의가 있고 화장품 정 보를 제공하는 마케팅 사용 시 주관적인 만족감 보다는 객관적이고 신뢰할 수 있는 정보를 수용했을 때 추천의도가 더 강해진다는 것 을 확인하였다. 후속 연구에서는 연령과 성별의 제한 없이 대상자 와 조사지역을 폭넓게 확대하고 다양한 변인들을 적용한 체계적인 연구가 이루어 질 것을 기대한다.

\section{Acknowedgements}

This work was supported by the Sungshin Women's University Research Grant of 2019.

\section{Author's contribution}

SHJ contributed to research questionnaire and to collect data base. SHY assisted the revision of the manuscript. CHP managed and designed the research project. All authors read and approved the final manuscript.

\section{Author details}

Son-Hyo Jung (PhD student), Department of Cosmetics Engineering, Konkuk University, 120 Neungdongro, Gwangjin-gu, Seoul 05029, Korea; Seon-hee You (Professor), Department of Skincare, Dongnam Health University, 50, Cheoncheon-ro, 75beon-gil, Jangangu, Suwon-si, Gyeonggi-do 16328, Korea; Cho-Hi Park (Professor), Department of Beauty Industry, Sungshin University, 55, Dobong-ro 76ga-gil, Gangbuk-gu, Seoul 01133, Korea.

\section{References}

Baron RM, Kenny DA. The moderator mediator variable distinction in social psychological research: conceptual, strategic and statistical considerations. Journal of Personality and Social Psychology, 51: 1173-1182, 1986.

Cronin JJ, Taylor SA. Measuring service quality: a reexamination 
and extension. Journal of Marketing, 56: 55-68, 1992.

Chang EK, Lee HK. A study on the factors influencing smartphone user satisfaction. Journal of Consumption Culture, 3: 129-145, 2010.

Choi SK. The Information search of herbal cosmetic consumers and their purchase conditions according to store types. Journal of the Korean Society of Design Culture, 17: 635643, 2011.

Joung JS. The effects of the characteristics of social mediabased beauty service information on information satisfaction, word-of-mouth intention and visit intention. Journal of the Korea Society of Beauty and Art, 20: 303318, 2019.

Kim SD, Ha YK. The mediating effects of customer-company identification on the relationship between service quality and referral intention: focused on the hotel restaurants. Tourism Research, 41: 1-19, 2016.

Kim G, Ye J. A study of types of on-line consumer information search behavior by information search motive. The Korean Journal of Advertising, 20: 161-175, 2009.

Kim MJ, Rhee KC. A study on the purchasing orientation of cosmetics by information search types of female consumers. Consumer Policy and Education Review, 3: 1-15, 2007.

Kang MK, Lee SS. Consumer satisfaction according to consumer's information search elements. Family and Environment Research, 36: 29-46, 1998.

Kwak DS, Yim KH, Kwon JH. Study on the influence of mobile application interactivity on flow and purchase intention. Journal of Digital Convergence, 10: 165-176, 2012.

Kim DJ. Using characteristics affects satisfaction in sports application as well as re-use and recommendation of the application. The Korean Journal of Sport, 12: 263-274, 2018.

Kim JA, Oh YK. Purchase behavior and satisfaction of onlineonly brand cosmetics. Asian Journal of Beauty and Cosmetology, 16: 32-41, 2018.

Ko MA, Kim JY, Lee MK. Reserach on how convergence marketing influences on consumer satisfaction and purchasing intention. International Journal of Tourism and Hospitality Research, 29: 241-252, 2015.

Koo HG, Rha JY. A study to explore female consumer's cosmetics using context by observation and in-depth interview approaches. Journal of Consumption Culture,
18: 147-179, 2015.

Lee JS, Jung SH, Shin MK. A study on multichannel consumer's choice of the information search and shopping channel. Korean Consumption Culture Association, 15: 21-45, 2012.

Lee SH, Kim ES, Joo YJ. The effect of career womens' appearance management behaviors on cosmetics shopping trends \& the purchase satisfaction degrees. Journal of the Korean Society of Design Culture, 23: 629641, 2017.

Park EJ, Jung YJ. Effects of e-reviews on purchase intention for cosmetics. Korean Journal of Human Ecology, 22: 343355, 2013.

Park EH, Ku YS. Cosmetics behavior and purchasing behavior according to female cosmetics consumer' shopping propensity typology. Journal of Fashion Business, 15: 2842, 2011.

Ryu MH, Lee SS. Undergraduate consumers' repurchase intention and recommendation intention depending on the safety satisfaction with ready-to-eat foods. Journal of Consumption Culture, 16: 91-115, 2013.

Reynolds KE, Beatty SE. Customer benefits and company consequences of customer-salesperson relationships in retailing. Journal of Retailing, 75: 11-33, 1999.

Roh KS. A well-informed statistical analysis of a paper. HanBit academy, Seoul, pp122, 2014.

Sung KW, Lee YJ. A study on the purchasing behavior of cosmetics through the classification of information retrieval attitudes. Statistical Consultation, 19: 31-59, 2006.

Song JJ. Statistical analysis method of SPSS/AMOS required for thesis preparation. 21Cbook, Paju, p100, 2015.

Yong UJ, Jin YM. The effects of men's Interest in beauty and information search on the beauty care behavior. Journal of the Korean Society of Design Culture, 24: 445-453, 2018.

Zheng QN, Noh WH. A study on the effect of online word of mouth information characteristics and brand Image on consumer's purchase intention in SNS: focused on Korea cosmetic brand in China SNS. Journal of Distribution and Logistics, 3: 5-18, 2016.

Zhang J, Koo HG. A study on information search of Chinese women cosmetics consumers who living in Beijing. Journal of Consumption Culture, 20: 169-197, 2017. 


\section{국문초록}

\section{소비자의 화장품 정보탐색행동과 만족도 및 추천의도의 관계 연구}

손효정 ${ }^{1}$, 유선희 ${ }^{2}$, 박초희 ${ }^{3 *}$

${ }^{1}$ 건국대학교 화장품공학과, 서울, 한국

${ }^{2}$ 연성대학교 뷰티스타일리스트과 스킨케어전공, 경기도 안양, 한국

${ }^{3}$ 성신여자대학교 뷰티산업학과, 서울, 한국

목적: 본 연구에서는 뷰티와 화장품에 관심이 많고 정보탐색 및 검색에 어려움이 없는 20 대 여성을 중심으로 화장품 구매를 위해 시도하는 정보 탐색행동과 만족도 및 추천의도에 미치는 영향과 관계를 규명함으로써 화장품 시장의 마케팅 대상인 20 대 여성 화장 품 소비자를 이해할 수 있는 자료를 제공하고 소비자 중심의 화장품 정보제공 및 접근방법의 다양화 방안을 제시하고자 하였다. 방 법: 본 연구를 위해 수집된 자료는 SPSS WIN 25.0 프로그램을 이용하여 분석하였다. 연구대상자의 일반적 특성과 화장품 정보탐 색의 이용특성을 파악하기 위해 빈도와 백분율을 산출하였고, 측정변수의 요인분석 및 신뢰도 분석, 도출된 요인간 상관관계분석과 화장품 정보탐색과 만족도 추천의도 간의 영향과 관계를 파악하기위해 회귀분석 및 매개효과 분석을 실시하였다. 결과: 요인분석과 상관관계를 분석한 결과 구매만족도와 추천의도가 비교적 높은 상관관계를 보였다. 회귀분석을 실시한 결과 추천의도가 화장품 정 보탐색에 유의미한 영향을 미치는 것으로 분석되었고 화장품 정보탐색행동이 추천의도에 영향을 미칠 때 만족도가 매개효과를 나 타내는 것으로 분석되었다. 결론: 소비자들은 객관적이고 신뢰할 수 있는 정보를 수용했을 때 추천의도가 더 강해진다는 것이 확인 됨으로써 화장품 마케팅 수단으로 사용되는 정보제공 시 신뢰할 수 있는 객관적 자료를 제시하여 마케팅의 긍정적 효과를 기대해 볼 수 있을 것이다.

핵심어: 소비자, 화장품정보탐색, 만족도, 추천의도, 이용특성

이 논문은 2019년도 성신여자대학교 학술연구조성비 지원에 의하여 연구되었음.

\section{참고문헌}

강미옥, 이승신. 소비자 정보탐색 요소에 따른 소비자 만족. 대한가정학회지, 36: 29-46, 1998.

곽동성, 임기홍, 권진희. 모바일 애플리케이션의 상호작용성이 플로우(flow)와 구매의도에 미치는 영향에 관한 연구: 구매

등급을 조절효과로. 디지털정책연구, 10: 165-176, 2012.

고미애, 김지연, 이규면. 외식기업 컨버전스마케팅이 만족도와 구매의도에 미치는 영향연구. 관광연구저널, 29: 241-

$252,2015$.

김균, 예종석. 정보탐색 동기에 따른 온라인 정보탐색 유형에 관한 연구. 광고학연구, 20: 161-175, 2009.

김민정, 이기춘. 여성소비자의 정보탐색유형별 화장품 구매성향 연구. 소비자정책교육연구, $3: 1-15,2007$.

김성대, 하용규. 고객-기업 동일시가 서비스품질과 추천의도의 관계에 미치는 매개효과: 호텔레스토랑을 중심으로. 한국

관광산업학회, 41: 1-19, 2016.

김진아, 오윤경. 온라인전용 브랜드 화장품의 구매행태와 만족도. 아시안뷰티화장품학술지, 16: 32-41, 2018.

구혜경, 나종연. 여성 소비자의 화장행동 분석을 통한 화장 맥락의 이해. 소비문화연구, 18: 147-179, 2015.

노경섭. 제대로 알고 쓰는 논문 통계분석. 한빛아카데미, 서울, pp122, 2014.

류미현, 이승신. 대학생소비자의 즉석섭취식품 안전만족도에 따른 재구매의도 및 추천의도. 소비문화연구, 16: 91-115,

2013.

박은주, 정유진. 온라인 리뷰 탐색이 화장품 구매의도에 미치는 영향. 한국생활과학회지, $22: 343-355,2013$. 
박은희, 구양숙. 화장품 소비자의 쇼핑성향 유형에 따른 화장행동 및 구매행동. 패션비즈니스, 15: 28-42, 2011. 성경화, 이윤지. 정보탐색태도의 유형화를 통한 화장품 구매성향 연구. 통계상담, 19: 31-59, 2006. 송지준. 논문작성에 필요한 SPSS/AMOS 통계분석방법. 21세기사, 파주, p100, 2015. 이정선, 정순희, 신민경. 멀티채널 소비자의 정보탐색 및 구매 채널선택에 관한 연구. 소비문화연구, 15: 21-45, 2012. 이순희, 김은실, 주영주. 직장여성의 외모관리행동이 화장품 쇼핑성향 및 화장품 구매만족도에 미치는 영향. 한국디자인문 화학회지, 23: 629-641, 2017.

용의진, 진용미. 남성들의 뷰티 관심도와 정보탐색이 뷰티관리행동에 미치는 영향. 한국디자인문화학회지, 24: 445-453, 2018.

장금혜, 구혜경. 북경 여성 소비자의 화장품 정보탐색에 관한 연구. 소비문화연구, 20: 169-197, 2017. 장은경, 이후경. 스마트폰 이용만족도 영향요인에 관한 연구. 소비문화연구, 3: 129-145, 2010. 정천남, 노원희. SNS상의 온라인 구전정보 특성 및 브랜드 이미지가 구매의도에 미치는 영향: 중국 SNS상의 한국 화장품 브랜드를 대상으로. 유통물류연구, 3: 5-18, 2016.

정지선. SNS 뷰티서비스 정보특성이 정보만족, 구전의도 및 방문의도에 미치는 영향. 한국인체미용예술학회지, 20: 303318, 2019.

최수경. 점포 유형에 따른 한방화장품 소비자의 정보 탐색과 구매 실태. 한국디자인문화학회지, 17: 635-643, 2011. 


\section{中文摘要}

\section{消费者探索化妆品信息行为与满意度和推荐意愿的关系}

孫效廷 ${ }^{1}$, 柳宣熙 ${ }^{2}$, 朴初結 $^{3 *}$

建国大学化妆品工学科, 首尔, 韩国

2研成大学美容设计科皮肤美容专攻, 京畿道安阳市, 韩国

诚信女子大学美容产业学科，首尔，韩国

目的: 本研究旨在通过评估女性化妆品消费者对信息探索行为和满意度以及推荐意图的影响以及与它们之间的关 系, 从而提出可了解20多岁女性化妆品消费者的数据, 并提出多种使以消费者为中心的化妆品信息和多样化的 方案。方法: 采用SPSS WIN 25.0程序对收集到的数据进行分析。我们计算了频率和百分比, 不仅可以确定研究 对象的一般特征，还可以识别与化妆品查询和信息有关的潜在利用特征。此外，进行了回归分析和中间效应分 析, 以确定这些因素之间的效应和关系。此外, 还进行了可靠性分析, 得出的因素与化妆品信息的推荐程度和 满意度之间的相关性分析。结果: 结果显示出客户购买满意度和推荐意愿之间的相关性较高。此外, 回归分析结 果表明, 推荐意图对化妆品的信息搜索具有显着影响, 而当化妆品信息搜索行为影响推荐意图时, 满意度显示 出中介效应。结论：这项研究强调，当消费者提供可靠，客观的信息（进而被用作化妆品的营销工具）时，他们 更有可能期望获得积极的营销效果和建议。

关键词: 消费者，化妆品信息，满意度，推荐意愿，使用特性 
